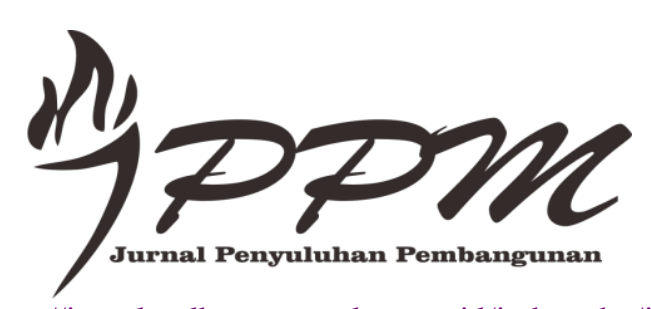

http://jurnal.polbangtanmalang.ac.id/index.php/jppm

Jurnal Penyuluhan Pembangunan Volume 1, Nomor 1 Tahun 2019

\title{
Penyuluhan Tentang Pembuatan Fermentasi Jerami Kangkung Menggunakan trichoderma,sp Sebagai Pakan Ternak Sapi Potong di Desa Babatan Kecamatan Balongpanggang Kabupaten Gresik
}

\section{Extension About Making Fermented Kale Straw Using Trichoderma, sp As Beef Cattle Feed in Babatan Village, Balongpanggang District, Gresik Regency}

\author{
Khairurrizaq $^{* 1}$, Ismulhadi ${ }^{2}$, Dewi Ratih Ayu Daning ${ }^{3}$ \\ 1,2,3 Program Studi Penyuluhan Peternakan dan Kesejahteraan Hewan, Polbangtan Malang \\ e-mail: *11Khairurrizaq1977@gmail.com
}

\begin{abstract}
Abstrak
Pemanfaatan jerami kangkung yang belum optimal dilakukan dengan peningkatan kualitas melalui teknologi fermentasi menggunakan kapang trichoderma,sp. Kajian ini bertujuan untuk Mendeskripsikan perilaku petani tentang pembuatan fermentasi jerami kangkung menggunakan trichoderma,sp sebagai pakan ternak sapi potong. Mendeskripsikan kandungan nutrisi fermentasi jerami kangkung menggunakan trichoderma,sp. Menyusun rancangan penyuluhan pembuatan fermentasi jerami kangkung menggunakan trichoderma,sp sebagai pakan ternak sapi potong. Mendeskripsikan hasil evaluasi penyuluhan pembuatan fermentasi jerami kangkung menggunakan trichoderma,sp sebagai pakan ternak sapi potong. Kajian dilakukan di Desa Babatan Kecamatan Balongpanggang Kabupaten Gresik. Maret sampai Mei 2018. Sampel 40 responden, ditentukan melalui purposive sampling. Pengumpulan data melalui penyebaran koesioner dan observasi, dikembangkan dari matriks kisi - kisi instrumen sesuai taksonomi bloom. Analisis data menggunakan tabulasi dan pemisahan data. Dilanjutkan dengan menentukan interval dan membuat garis kontinum. Hasil kajian menunjukkan bahwa : 1) Pengetahuan petani tergolong "Tinggi" setelah penyuluhan. Dari 47\%, meningkat menjadi 77,25\%. 80,05\% petani memiliki sikap "Positif" sedangkan keterampilan petani tergolong "Sangat Terampil" dengan persentase 76,95\%. 2) Kandungan nutrisi mengalami peningkatan. PK dari 6,13\% menjadi $10,55 \%$, dan LK 3,2\% menjadi 4,08\%. Sedangkan SK dari 23,6\% menjadi 28,65. 3) Materi penyuluhan yaitu, Pembuatan fermentasi jerami kangkung menggunakan trichoderma,sp sebagai pakan ternak sapi potong. 4) Terdapat hubungan antara pendidikan dan umur dengan perilaku petani. Hubungan antara pendidikan dengan perilaku bersifat searah, sedangkan hubungan antara umur dengan perilaku bersifat tidak searah.
\end{abstract}

Kata kunci : Penyuluhan, sapi potong, fermentasi, trichoderma,sp, perilaku 
Khairurrizaq, Ismulhadi dan Dewi Ratih Ayu Daning, Penyuluhan Tentang Pembuatan Fermentasi Jerami Kangkung Menggunakan trichoderma,sp Sebagai Pakan Ternak Sapi Potong di Desa Babatan Kecamatan Balongpanggang

\begin{abstract}
Utilization of water spinach straw which has not been optimal is done by increasing quality through fermentation technology using trichoderma mold, sp. This study aims to describe the behavior of farmers about making kale straw fermentation using trichoderma, sp as beef cattle feed. Describe the nutritional content of water spinach straw using trichoderma, sp. Arranging the design of counseling for making kale straw fermentation using trichoderma, sp as beef cattle feed. Describing the results of the evaluation of counseling for making kale straw fermentation using trichoderma, sp as beef cattle feed. The study was conducted in Babatan Village, Balongpanggang District, Gresik Regency. March to May 2018. Samples of 40 respondents were determined through purposive sampling. Data collection through questionnaire deployment and observation, developed from the instrument grid matrix according to the taxonomy of bloom. Data analysis uses tabulation and data separation. Followed by determining the interval and making a continuum line. The results of the study indicate that: 1) Farmers' knowledge is classified as "High" after counseling. From 47\%, it increased to $77.25 \%$. $80.05 \%$ of farmers have a "Positive" attitude while the skills of farmers are classified as "Very Skilled" with a percentage of 76.95\%. 2) Nutritional content has increased. PK from $6.13 \%$ to $10.55 \%$, and $L K 3.2 \%$ to $4.08 \%$. While SK from $23.6 \%$ to 28.65. 3) Extension material, namely, making kale straw fermentation using trichoderma, sp as beef cattle feed. 4) There is a relationship between education and age with the behavior of farmers. The relationship between education and behavior is unidirectional, while the relationship between age and behavior is not in the same direction.
\end{abstract}

Keywords : Extension, beef cattle, fermentation, trichoderma, sp, behavior

\title{
I. PENDAHULUAN
}

Luas Balongpanggang 6.415,39 Ha luas lahan persawahan 5.112,70 Ha, (BPS, Kabupaten Gresik, 2017). Selain jagung, kangkung darat menjadi komoditas yang dikembangkan oleh petani, Produksi biji kangkung rata - rata 3.161,5 ton/tahun (BPP Balongpanggang, 2017). 1,5 ton bijikangkung menghasilkan 2,5 ton jerami kangkung. Total produksi jerami kangkung mencapai 5.269,16 ton/tahun. Direktorat Jenderal Budidaya Ternak Ruminansia, merilis kebutuhan pakan bagi ternak sapi adalah sebesar 6,25 kg BK/ST/hari, (Sitindaon (2013: 19). Hal ini menunjukkan bahwa produksi jerami kangkung mampu mencukupi kebutuhan pakan 5279 ekor ternak sapi di Kecamatan Balongpanggang selama 5 bulan atau 159,70 hari.

Sapi potong yang bekembang di Indonesia, merupakan bangsa sapi tropis terdiri dari sapi lokal dan sapi impor, (Sulaiman, 2009: 4). Umumnya masyarakat pedesaan melakukan usaha penggemukan dan penyediaan bibit sapi potong dengan sistem kereman, penyediaan pakan mengandalkan hijauan berupa rumput lapang, legum dan limbah hasil pertanian. Pakan yang diberikan pada ternak sapi penggemukan diarahkan untuk mencapai pertambahan bobot badan yang setinggi - tingginya dalam waktu relatif singkat.

Pemilihan hijauan pakan ternak harus diperhatikan disukai ternak atau tidak, mengandung toxin (racun) atau tidak yang dapat membahayakan perkembangan ternak Jurnal Penyuluhan Pembangunan 1 (1) 2019 53-63 | 54 
Khairurrizaq, Ismulhadi dan Dewi Ratih Ayu Daning, Penyuluhan Tentang Pembuatan Fermentasi Jerami Kangkung Menggunakan trichoderma,sp Sebagai Pakan Ternak Sapi Potong di Desa Babatan Kecamatan Balongpanggang Kabupaten Gresik

yang mengkonsumsi, (Sulaiman,. 2009: 15). Jerami kangkung merupakan salah satu limbah pertanian yang dimanfaatkan untuk memenuhi kebutuhan pakan ternak sapi bagi peternak. Kangkung merupakan salah satu jenis sayuran yang kaya gizi. sumber vitamin A, dan C, mineral besi, kalsium. ternak yang berakibat meningkatnya daya cerna bahan pakan dan menjaga kesehatan ternak, (Lamid,. 2013: 3). Dahlan, et al (2013: 17), melaporkan hasil uji analisis proksimat jerami kangkung darat memiliki nilai kandungan bahan kering sebesar 84,7 \%, protein kasar 6,13\%, serat kasar 23,6 \% dan lemak kasar $3,2 \%$, yang cukup untuk membantu memenuhi kebutuhan nutrisi pakan ternak ruminansia sebagai pakan tambahan.

Jerami kangkung merupakann limbah kangkung setelah di ambil bijinya. Pemanfaatan jerami kangkung yang belum optimal oleh peternak bagi pemenuhan kebutuhan pakan ternak sapi merupakan permasalahan yang dihadapi oleh peternak. Pemanfaatan jerami kangkung sebagai pakan ternak dapat di optimalkan dengan peningkatan kualitas melalui teknologi fermentasi. Fermentasi mempunyai kontribusi positif menjaga keseimbangan komposisi mikroorganisme dalam sistem pencernaan ternak, yang berakibat meningkatnya daya cerna bahan pakan dan menjaga kesehatan ternak, (Lamid,. 2013: 3). Salah satu peningkatan kualitas pakan melalui tekhnolgi fermentasi adalah dengan menggunakan kapang trichoderma,sp.

Trichoderma,sp merupakan sejenis cendawan yang termasuk kelas Ascomycetes,( Ariyantis, 2015: 10). Pemanfaatan jamur trichoderma,sp sebagai starter dalam proses fermentasi ini dirasa paling cocok dan sesuai dengan tujuan fermentasi, yaitu untuk meningkatkan kandungan nutrisi diantaranya meningkatkan kadar kalsium dan fospor (Nohong, et al. 2015: 30). Rukhmani menyatakan, keuntungan dari inokulasi limbah dengan fungi trichoderma,sp. yaitu kandungan protein meningkat dan enzim yang diproduksi fungi membantu dalam kecernaan bahan, (Ariyantis, (2015: 13 - 14). Pada fermentasi 8 hari rataan kandungan protein kasar adalah 6,56 $\pm 0,65 \%$ dan setelah 12 hari fermentasi kandungan protein sebesar 6,60 $\pm 0,79 \%$. Peningkatan kandungan PK disebabkan dalam proses ditambahkan sumber $\mathrm{N}$ yang berupa urea, dengan adanya kapang sebagian $\mathrm{N}$ dikonsumsi oleh kapang untuk membentuk protein dan lama fermentasi yang terbaik adalah $8-12$ hari pada suhu ruang dan kondisi aerob (Supriyati, T et al. 2010)

Sarwono dalam Gineung (2010: 17), prilaku adalah merupakan hasil dari segala macam pengalaman serta interaksi manusia dengan lingkungannya yang terwujud dalam bentuk pengetahuan, sikap dan tindakan. Latipun, pengetahuan seseorang mempengaruhi cara pandangnya terhadap sesuatu, serta memudahkan dalam menerima/mengadopsi perilaku yang positif (Misbahul, et al. 2014: 72). Astuti dan Honorita dalam Ma'ruf (2015: 32) menyimpulkan bahwa pengetahuan sebagai alat jaminan yang sangat penting untuk terbentuknya tindakan seseorang dari pengalaman, dan perilaku didasarkan atas pengetahuan akan lebih langgeng dibandingkan dengan tanpa didasari pengetahuan

Ismulhadi dalam Ma'ruf (2016: 34), menyatakan sikap yaitu kecenderungan untuk tidak prasangka terhadap hal - hal yang belum dikenal, mencoba sesuatu yang baru, mau bergotong royong dalam menyelesaikan masalah - masalah bersama dan menimbulkan sikap swadaya dan swadana. Bloom membagi sikap dalam beberapa kategori, yaitu: (a) reciving / attending, yakni semacam kepekaan dalam menerima rangsangan (stimulasi). (b) Responding atau jawaban, yakni reaksi yang diberikan oleh seseorang terhadap stimulasi yang datang dari luar. (c) Valuing (penilaian) berkenaan dengan nilai dan kepercayaan terhadap gejala atau stimulus. (d) organisasi yakni pengembangan dari nilai 
Khairurrizaq, Ismulhadi dan Dewi Ratih Ayu Daning, Penyuluhan Tentang Pembuatan Fermentasi Jerami Kangkung Menggunakan trichoderma,sp Sebagai Pakan Ternak Sapi Potong di Desa Babatan Kecamatan Balongpanggang Kabupaten Gresik

ke dalam satu sistem organisasi, termasuk hubungan satu nilai dengan nilai lain, pemantapan, dan prioritas nilai yang telah dimilikinya (Rosa, F O. 2015: 25). Notoatmojo dalam Eka, et al (2014: 74), menambahkan, proses perubahan pada ketrampilan seseorang melibatkan hal berikut, yaitu persepsi, kesiapan, respon terpimpin, mekanisme, respons yang tampak kompleks, penyesuaian dan penciptaan.

\section{METODE PENELITIAN}

Pembuatan fermentasi jerami kangkung menggunakan trichoderma,sp dilakukan di Laboratorium Nutrisi dan Makanan Ternak Sekolah Tinggi Penyuluhan Pertanian (STPP) - Malang. Uji kandungan dilakukan di Laboratorium Universitas Brawijaya Malang. Kajian perilaku dilakukan di Desa Babatan Kecamatan Balongpanggang. trichoderma,sp yang digunakan diperoleh dari Balai Penelitian Teknologi Pertanian (BPTP) Malang, terbuat dari media jagung, sedangkan jerami kangkung di peroleh dari limbah pertanian di Kecamatan Balongpanggang. Proses fermentasi dilakukan selama 10 hari dan dilakukan pada suhu ruang dan kondisi aerob.

Pengumpulan data dengan koesioner yang dikembangkan dari matriks kisi - kisi instrumen, bentuk pernyataan variabel dan dimensi. Skala likert dan rating scale menjadi alat pengukuran pengetahuan, sikap dan keterampilan. Uji validitas instrument dengan pengajuan validitas isi, konstruksi dilanjutkan dengan uji validitas butir. Uji validitas isi dilakukan melalui kisi - kisi instrument atau matriks pengembangan instrumen sebelum menyusun daftar pertanyaan. Pengujian validitas konstruksi dapat digunakan pendapat ahli (judgment expert), setelah instrumen di konstruksi tentang aspek - aspek yang akan diukur dengan berlandaskan teori tertentu, selanjutnya dikonsultasikan kepada ahli, minimal 3 orang dan telah bergelar doktor atau yang berkomepeten (Sugyono, 2016: 172).

Data yang diperoleh di lakukan tabulasi, dan pemisahan sesuai kebutuhan, kemudian menentukan interval kelas. Hubungan antara karakteristik dengan perilaku, menggunakan tabulasi silang, membandingkan antara capaian dengan target setiap variabel yang di ukur. Penentuan :

* Skor maksimum = Skor jawaban tertinggi $\mathrm{x} \sum$ pertanyaan $\mathrm{x} \sum$ Responden

* Skor Minimmum = Skor jawaban terendah $\mathrm{x} \sum$ pertanyaan $\mathrm{x} \sum$ Responden

* Nilai Perilaku $\quad=\sum$ jawaban Responden : Skor Maksimum x 100\%

* Jumlah kelas = Pengetahuan 5, sikap 4, dan keterampilan 2

* Jangkauan interval = Skor maks - skor min : $\sum$ kelas inerval $\mathrm{x} 100 \%$

\section{Pembuatan Fermentasi Jerami Kangkung}

* Membuat Larutan Starter trichoderma, sp.

* Menyiapkan molasses 0,25\%. Menyiapkan Urea 0,25\%. Menyiapkan jamur trichoderma, sp 4\%. Menyiapkan air bersih/aquades 60 - 70\%. campurkan semua bahan. Simpan selama 24 jam

* Menyiapkan Jerami Kangkung

Jerami kangkung di timbang sebanyak 1 kilogram. Kemudian di bagi menjadi 10 bagian, 1 bagian seberat 100 gr. Setiap bagian disimpan dalam wadah sendiri sendiri atau terpisah

* Penyiapan Larutan Fermentasi 
Khairurrizaq, Ismulhadi dan Dewi Ratih Ayu Daning, Penyuluhan Tentang Pembuatan Fermentasi Jerami Kangkung Menggunakan trichoderma,sp Sebagai Pakan Ternak Sapi Potong di Desa Babatan Kecamatan Balongpanggang

Kabupaten Gresik

Stater yang sudah di simpan selama 2. Campurkan dengan air sebanyak $600 \mathrm{ml}$. Larutan disaring, agar tidak terdapat butiran kasar yang dapat mengganggu lobang sprayer saat penyemprotan. Larutan dimasukkan kedalam sprayer, dan siap untuk di pergunakan

* Pembuatan Fermentasi jerami kangkung

Jerami kangkung seberat 100 gr di sebar dengan ketinggian $3 \mathrm{~mm}$. Semprotkan dengan larutan starter trichoderma sebanyak 70 mililiter. Membentuk tumpukan kedua di atas tumpukan pertama. Semprotkan dengan larutan starter, hingga membentuk 10. Campurkan merata . Masukkan dalam plastik. Simpan selama 10 hari, untuk menjaga kelembaban.

* Uji Laboratorium

Pastikan fermentasi berjalan dengan baik, amati warna, bau, tekstur sebelum dilakukan di Lab. Universitas Brawijaya Malang. PK, SK, LK, dan abu

\section{HASIL DAN PEMBAHASAN}

Pengetahuan dikelompokkan menjadi 6 tingkatan yaitu: tahu, memahami, aplikasi, analisis, sintesis, dan kreasi. Setiap tingkatan terdapat Item pernyataan dengan perolehan skor masing - masing. Sikap merupakan ekspresi yang mencerminkan perasaan (inner feeling), seseorang senang atau tidak senang, suka atau tidak suka dan setuju atau tidak setuju terhadap suatu objek, (Schifman dan Kanuk,; Ade, Sudarsana, Ketut. 2014: 45). Keterampilan adalah kemampuan melakukan sesuatu dengan baik, untuk mengaplikasikan pengetahuan teoritis dalam situasi tertentu (Iverson,; Megantoro, 2015: 4).

Hasil tabulasi dan analisis data, diperoleh data - data sebagai berikut :

Tabel 1. Kesenjangan dan Capaian Pengetahuan Pra dan Pasca

\begin{tabular}{|c|c|c|c|c|c|c|}
\hline \multirow{3}{*}{ No } & \multicolumn{3}{|c|}{ Sub Variabel Pengetahuan } & \multicolumn{3}{|c|}{ Capaian } \\
\hline & \multirow{2}{*}{ Tingkatan } & \multirow{2}{*}{ Item Pernyataan } & \multicolumn{2}{|c|}{ Nilai } & \multicolumn{2}{|c|}{ Capaian (\%) } \\
\hline & & & Pra & Post & Pra & Post \\
\hline 1 & Tahu & Devinisi limbah kangkung & 245 & 376 & $\begin{array}{c}61,2 \\
5\end{array}$ & 94 \\
\hline 2 & Memahami & Pemanfaatan jerami kangkung & 219 & 333 & $\begin{array}{c}54,7 \\
5\end{array}$ & $\begin{array}{c}83,2 \\
5\end{array}$ \\
\hline 3 & Aplikasi & Pernah mencoba fermentasi & 197 & 315 & $\begin{array}{c}49,2 \\
5\end{array}$ & $\begin{array}{c}78,7 \\
5\end{array}$ \\
\hline 4 & Analisis & Tahu seleksi bahan fermentasi & 169 & 293 & $\begin{array}{c}42,2 \\
5\end{array}$ & $\begin{array}{c}73,2 \\
5\end{array}$ \\
\hline 5 & Sinstesis & Tahu keunggulan trichoderma & 160 & 278 & 40 & 69,5 \\
\hline 6 & Kreasi & Tahu cara fermentasi yang baik & 138 & 259 & 34,5 & $\begin{array}{c}64,7 \\
5\end{array}$ \\
\hline \multicolumn{3}{|c|}{ Jumlah } & 1128 & 1854 & \multirow{2}{*}{47} & 77,2 \\
\hline Jun & ah Nilai Targ & yang Ingin Dicapai & & & & 5 \\
\hline
\end{tabular}


Khairurrizaq, Ismulhadi dan Dewi Ratih Ayu Daning, Penyuluhan Tentang Pembuatan Fermentasi Jerami Kangkung Menggunakan trichoderma,sp Sebagai Pakan Ternak Sapi Potong di Desa Babatan Kecamatan Balongpanggang

Tabel 2. Kesenjangan dan Capaian Sikap Pra dan Pasca

\begin{tabular}{|c|c|c|c|c|c|c|}
\hline \multirow{3}{*}{ No } & \multicolumn{3}{|c|}{ Sub Variabel Sikap } & \multicolumn{3}{|c|}{ Capaian } \\
\hline & \multirow{2}{*}{ Tingkatan } & \multirow{2}{*}{ Item Pernyataan } & \multicolumn{2}{|c|}{ Nilai } & \multicolumn{2}{|c|}{ Capaian $(\%)$} \\
\hline & & & Pra & Post & Pra & Post \\
\hline 1 & Menerima & Mau dan ikut dalam kegiatan & 226 & 285 & 56,5 & $\begin{array}{c}71,2 \\
5\end{array}$ \\
\hline 2 & Merespon & Mendukung fermentasi jerami & 268 & 345 & 67 & $\begin{array}{c}86,2 \\
5\end{array}$ \\
\hline 3 & menghargai & Meyakini nilai positif fermentasi & 285 & 285 & $\begin{array}{c}71,2 \\
5\end{array}$ & $\begin{array}{c}71,2 \\
5\end{array}$ \\
\hline 4 & Organisasi & mau mengajak orang lain & 318 & 336 & 79,5 & 84 \\
\hline 5 & Karakterisasi & Mau Menerapkan fermentasi & 341 & 350 & $\begin{array}{c}85,2 \\
5 \\
\end{array}$ & 87,5 \\
\hline $\begin{array}{l}\text { Jum } \\
\text { Jum }\end{array}$ & Ah Nilai Tat & ng Ingin Dic & $\begin{aligned} 1438 \\
2\end{aligned}$ & 1601 & 71,9 & $\begin{array}{c}80,0 \\
5\end{array}$ \\
\hline
\end{tabular}

Sumber: Data diolah, 2018

Tabel 3. Kesenjangan dan Capaian Keterampilan Pra dan Pasca

\begin{tabular}{|c|c|c|c|c|c|c|}
\hline \multirow{3}{*}{ No } & \multicolumn{4}{|c|}{ Sub Variabel Keterampilan } & \multirow{2}{*}{\multicolumn{2}{|c|}{$\begin{array}{c}\text { Capaian } \\
\text { Capaian }(\%) \\
\end{array}$}} \\
\hline & \multirow{2}{*}{ Tingkatan } & \multirow{2}{*}{ Item pengamatan } & \multicolumn{2}{|c|}{ Nilai } & & \\
\hline & & & Pra & Post & Pra & Post \\
\hline \multirow[t]{2}{*}{1} & Kecepatan & mempersiapkan & 91 & 249 & 28,4 & 77,8 \\
\hline & & peralatan dan bahan dengan cepat & & & 3 & 1 \\
\hline \multirow[t]{2}{*}{2} & Akurasi & Kemampuan menyusun urut - urutan & 86 & 237 & 26,8 & 74,0 \\
\hline & & $\begin{array}{l}\text { pengerjaan mulai dari persiapan alat } \\
\text { dan bahan sampai pada pelaksanaan }\end{array}$ & & & 7 & 6 \\
\hline \multirow[t]{2}{*}{3} & Bentuk & Keterampilan harus dilaksanakan & 84 & 255 & 26,2 & 79,6 \\
\hline & & $\begin{array}{l}\text { dengan kebutuhan energi yang } \\
\text { minimal }\end{array}$ & & & 6 & 8 \\
\hline \multirow[t]{2}{*}{4} & Kesesuaian & Kemampuan untuk menjustifikasi & 83 & 244 & 25,9 & 76,2 \\
\hline & & $\begin{array}{l}\text { sesuai hasil yang di inginkan. Dengan } \\
\text { melihat keserasian bentuk tekstur, } \\
\text { warna dan bau }\end{array}$ & & & 3 & 5 \\
\hline \multirow{2}{*}{\multicolumn{3}{|c|}{ Jumlah }} & 344 & 985 & 26,8 & \\
\hline & & & & & 7 & \\
\hline \multicolumn{3}{|c|}{ Jumlah Nilai Target yang Ingin Dicapai } & & 1280 & & \\
\hline
\end{tabular}

Tabel 4. Hasil Analisis Proxymat Jerami Kangkung 
Khairurrizaq, Ismulhadi dan Dewi Ratih Ayu Daning, Penyuluhan Tentang Pembuatan Fermentasi Jerami Kangkung Menggunakan trichoderma,sp Sebagai Pakan Ternak Sapi Potong di Desa Babatan Kecamatan Balongpanggang

\begin{tabular}{|c|c|c|c|c|c|c|c|}
\hline \multirow[b]{2}{*}{ No } & \multicolumn{7}{|c|}{ Kandungan Zat Makanan } \\
\hline & Uji Laboratorium & $\begin{array}{l}\mathrm{BK} \\
(\%)\end{array}$ & $\operatorname{Abu}(\%)$ & $\begin{array}{l}\text { PK } \\
(\%)\end{array}$ & $\begin{array}{l}\text { SK } \\
(\%)\end{array}$ & $\begin{array}{l}\text { LK } \\
(\%)\end{array}$ & $\mathrm{pH}$ \\
\hline 1 & Sesudah Fermentasi & 91,6 & 17,28 & 10,55 & 28,65 & 4,08 & 6,80 \\
\hline 2 & Sebelum Fermentasi & 84,7 & 13.32 & 6,13 & 23,6 & 3,2 & - \\
\hline
\end{tabular}

Tabel 5. Tabulasi Silang Hubungan Karakteristik dengan Perilaku Petani

\begin{tabular}{|c|c|c|c|c|c|c|c|c|c|}
\hline \multirow{2}{*}{\multicolumn{2}{|c|}{ KARAKTERISTIK }} & \multicolumn{6}{|c|}{ PERILAKU } & \multirow{2}{*}{\multicolumn{2}{|c|}{$\begin{array}{c}\text { RESPONDE } \\
\mathbf{N}\end{array}$}} \\
\hline & & \multicolumn{2}{|c|}{$\begin{array}{c}\text { Pengetahua } \\
\text { n }\end{array}$} & \multicolumn{2}{|c|}{ Sikap } & \multicolumn{2}{|c|}{$\begin{array}{c}\text { Keterampila } \\
\text { n }\end{array}$} & & \\
\hline & & Skor & $\begin{array}{c}\text { Targ } \\
\text { et }\end{array}$ & Skor & $\begin{array}{l}\text { Targ } \\
\text { et }\end{array}$ & Skor & $\begin{array}{c}\text { Targ } \\
\text { et }\end{array}$ & $\mathrm{Jml}$ & Persen \\
\hline \multirow{4}{*}{$\begin{array}{l}\text { PENDIDIK } \\
\text { AN }\end{array}$} & SD & 1006 & 1320 & 876 & 1100 & 503 & 704 & 22 & 55 \\
\hline & SMP & 595 & 780 & 534 & 650 & 340 & 416 & 13 & 32,5 \\
\hline & $\begin{array}{l}\text { SMA - } \\
\text { PT }\end{array}$ & 253 & 300 & 191 & 250 & 142 & 160 & 5 & 12,5 \\
\hline & Jumlah & 1854 & 2400 & 1601 & 2000 & 985 & 1280 & 40 & 100 \\
\hline \multirow{4}{*}{ UMUR } & $<41$ & 323 & 420 & 233 & 350 & 193 & 224 & 7 & 17,5 \\
\hline & $41-54$ & 1226 & 1620 & 1169 & 1350 & 624 & 864 & 27 & 67,5 \\
\hline & $>54$ & 265 & 360 & 233 & 300 & 153 & 192 & 6 & 15 \\
\hline & Jumlah & 1814 & 2400 & 1635 & 2000 & 1009 & 1280 & 40 & 100 \\
\hline
\end{tabular}

Sumber: Data diolah, 2018

Tabel 6. Pengelompokkan Nilai Perilaku Petani Berdasarkan Karakteristik

\begin{tabular}{|c|c|c|c|c|c|c|c|}
\hline \multicolumn{2}{|c|}{ KARAKTERISTIK } & \multicolumn{2}{|c|}{$\begin{array}{c}\text { PENGETAHUAN } \\
(\%)\end{array}$} & \multicolumn{2}{|c|}{ SIKAP (\%) } & \multicolumn{2}{|c|}{$\begin{array}{c}\text { KETERAMPILA } \\
\text { N (\%) }\end{array}$} \\
\hline \multirow{7}{*}{$\begin{array}{l}\text { Pendidika } \\
\text { n }\end{array}$} & & capaia & kesenjang & capaia & kesenjang & capaia & kesenjang \\
\hline & jenjang & $\mathrm{n}$ & an & $\mathrm{n}$ & an & $\mathrm{n}$ & an \\
\hline & $<=\mathrm{SD}$ & 15,24 & 84,76 & 79,63 & 20,37 & 71,44 & 28,56 \\
\hline & SMP & 77,28 & 22,72 & 82,15 & 17,85 & 81,73 & 48,27 \\
\hline & SMA - & & & & & & \\
\hline & PT & 84,33 & 15,67 & 76,4 & 23,6 & 88,75 & 11,25 \\
\hline & Rerata & $\mathbf{5 8 , 9 5}$ & & 78,39 & & 80,64 & \\
\hline \multirow{4}{*}{ Umur } & $<41$ & 76,90 & 23,1 & 66,57 & 33,43 & 86,16 & 11,84 \\
\hline & $41-54$ & 75,67 & 24,33 & 86,59 & 13,41 & 72,22 & 27,78 \\
\hline & $>54$ & 73,61 & 26,39 & 77,66 & 22,34 & 79,68 & 20,32 \\
\hline & Rerata & 75,93 & & 76,94 & & 79,35 & \\
\hline
\end{tabular}

Sumber: Data diolah, 2018

\section{Perilaku Petani Pra Penyuluhan}

47\% petani belum mengetahui pembuatan fermentasi jerami kangkung menggunakan trichoderma,sp. Pengetahuan petani termasuk kategori sangat rendah, dimana skor jawaban 40 responden adalah sebesar 1128. Skor tersebut terletak pada 
Khairurrizaq, Ismulhadi dan Dewi Ratih Ayu Daning, Penyuluhan Tentang Pembuatan Fermentasi Jerami Kangkung Menggunakan trichoderma,sp Sebagai Pakan Ternak Sapi Potong di Desa Babatan Kecamatan Balongpanggang Kabupaten Gresik

jangkaun antara 769 - 1153. sebanyak $61,25 \%$ sudah dapat mendevinisikan pengertian limbah kangkung

$71 \%$ petani memiliki sikap positif tentang cara pembuatan fermentasi jerami kangkung menggunakan trichoderma,sp. $85,25 \%$ petani memiliki karakterisasi untuk mengadopsi fermentasi jerami kangkung menggunakan trichoderma,sp

73,13\% petani masih rendah keterampilan membuat fermentasi jerami kangkung menggunakan trichoderma,sp. Skor 344, terletak pada diantara 320 - 642. Petani tergolong "Tidak Terampil"

\section{Nutrisi Jerammi Kangkung Pra dan Pasca Fermentasi}

Tabel 1 menunjukkan bahwa jerami kangkung yang belum dilakukan fermentasi, memiliki kandungan nutrisi lebih rendah. Fermentasi jerami kangkung menggunakan trichoderma,sp. Kandungan PK 10,55\%, dan LK 28,65\%. Peningkatan PK sebesar $4,32 \%$ dan LK 0,88\%. Kandungan SK juga mengalami perubahan dari 23,6 menjadi 28,65, terjadi kenaikkan 5,08\%.

Peningkatan kandungan protein kasar dan lemak kasar, disebabkan oleh adanya aktifitas mikroba yang bekerja untuk melakukan perombakan, sejalan dengan laporan Ariyantis, (2015: 13 - 14), trichoderma, $s p$ mengubah senyawa - senyawa yang ada di dalam substrat untuk pertumbuhan dan pembentukan protein. Perombakan ini terjadi karena proses fermentasi, fungi memproduksi enzim yang melakukan perombakan terhadap senyawa - senyawa kompleks, sehingga produksi yang terinokulasi tersebut merupakan bahan pakan dengan kandungan protein yang lebih tinggi.

\section{Rancangan Penyuluhan}

Materi penyuluhan yaitu pembuatan fermentasi jerami kangkung menggunakan kapang trichoderma, $s p$ sebagai pakan ternak sapi potong. digunakan kombinasi metode ceramah, diskusi dan demonstrasi cara dengan teknik pendekatan kelompok dan individu.

Penyuluhan bertujuan merubah perilaku petani dalam pemanfaatan jerami kangkung melalui fermentasi jerami kangkung menggunakan trichoderma,sp sebagai pakan ternak sapi potong.

Folder, dan media sesungguhnya serta power point, dibantu dengan media tayang berupa LCD proyektor. Hal ini dimaksudkan agar dapat meningkatkan daya menerima dan respon petani yang lebih baik, sehingga diharapkan dapat menumbuhkan minat.

Sasaran penyuluhan, petani ternak sapi potong keseluruhan dari responden dalam kajian yang tergabung dalam Gapoktan Babatan, Desa Babatan Kecamatan Balongpanggang Kabupaten Gresik Provinsi Jawa Timur

\section{Perilaku Petani Pasca Penyuluhan}

Nilai pengetahuan petani 1854 terletak diantara angka 1538 - 1923, termasuk pada kategori "Tinggi". Hal ini menunjukkan $77,25 \%$ petani memiliki pengetahuan pembuatan fermentasi jerami kangkung menggunakan trichoderma,sp. Terjadi peningkatan 30,25\%. 94\%, petani mampu mendevinisikan pengertian jerami kangkung dengan baik.

Skor sikap petani 1601 terletak diantara nilai 1201 - 1602. Menandakan 80,05\% petani memiliki sikap " Positif " tentang pembuatan fermentasi jerami kangkung menggunakan trichoderma,sp. Peningkatan tertinggi pada tingkatan merespon, mencapai 
Khairurrizaq, Ismulhadi dan Dewi Ratih Ayu Daning, Penyuluhan Tentang Pembuatan Fermentasi Jerami Kangkung Menggunakan trichoderma,sp Sebagai Pakan Ternak Sapi Potong di Desa Babatan Kecamatan Balongpanggang Kabupaten Gresik

$19,25 \%$ hal ini menunjukkan bahwa petani memiliki respon positif pembuatan fermentasi jerami kangkung menggunakan trichoderma,sp.

Nilai keterampilan 985 terletak diantara 642 - 1280. Petani tergolong "Terampil". Pada ketegori ini memiliki kemampuan yang baik melakukan pembuatan fermentasi jerami kangkung menggunakan trichoderma,sp. 76,95\%. Kemampuan tertinggi pada tingkatan bentuk, mampu melaksanakan dengan kebutuhan energi minimal

\section{Hubungan Karakteristik dengan Perilaku}

Hubungan pendidikan dengan pengetahuan bersifat searah. Hal ini ditunjukkan dengan semakin tinggi jenjang pendidikan petani, perolehan nilai pengetahuan semakin meningkat. Semakin tinggi umur petani tidak berpengaruh terhadap peningkatan pengetahuan. Semakin tinggi umur petani, perolehan nilai pengetahuan semakin menurun. Hubungan antara umur petani dengan pengetahuan bersifat tidak searah. Jenjang pendidikan dari SD sampai SMP nilai sikap semakin meningkat, sedangkan pada jenjang pendidikan SMA sampai PT perolehan nilai sikap mengalami penurunan. Hubungan antara jenjang pendidikan SD dan SMP dengan sikap bersifat searah. Sedangkan hubungan antara jenjang pendidikan SMA - PT dengan sikap bersifat tidak searah. Hal ini menunjukkan bahwa, semakin tinggi jenjang pendidikan petani tidak mempengaruhi sikap

Semakin tinggi umur petani, nilai sikap semakin meningkat. Hubungan antara umur dengan sikap petani bersifat searah. Hal ini menunjukkan bahwa, semakin tinggi umur petani, berpengaruh terhadap peningkatan nilai sikap. Semakin tinggi jenjang pendidikan petani, nilai keterampilan semakin meningkat. Hubungan antara pendidikan dengan keterampilan bersifat searah. Hal ini menunjukkan bahwa, semakin tinggi pendidikan petani, berpengaruh terhadap peningkatan keterampilan Semakin tinggi umur petani, nilai keterampilan semakin menurun. Hubungan antara umur dengan keterampilan bersifat tidak searah. Hal ini menunjukkan bahwa, semakin tinggi umur tidak berpengaruh terhadap peningkatan keterampilan.

\section{KESIMPULAN}

Hasil Analisis Proxymat fermentasi jerami kangkung menggunakan trichoderma,sp. Nutrisi jerami kangkung mengalami peningkatan. protein kasar 10,55\%, dan lemak kasar 28,65\%. Tingkat pengetahuan petani tentang cara pembuatan fermentasi jerami kangkung menggunakan trichoderma,sp sebagai pakan ternak sapi potong tergolong "Tinggi" setelah penyuluhan. Sebelum penyuluhan hanya $47 \%$, terjadi peningkatan pengetahuan sebesar 30,25\% dengan jumlah pencapaian sebesar 77,25\% dari target yang diharapkan $80,05 \%$ petani memiliki sikap "Positif" tentang pembuatan fermentasi jerami kangkung menggunakan trichoderma,sp sebagai pakan ternak sapi potong.

Keterampilan petani tentang cara pembuatan fermentasi jerami kangkung menggunakan trichoderma,sp sebagai pakan ternak sapi potong tergolong "Sangat Terampil" dengan persentase mencapai $76,95 \%$ dari yang diharapkan. Berdasarkan karakteristik pendidikan, perilaku petani tentang pembuatan fermentasi jerami kangkung menggunakan trichoderma,sp sebagai pakan ternak sapi potong, persentasenya rata - rata $72,66 \%$ dari target yang diharapkan. Sedangkan berdasarkan karakteristik umur, petani memperoleh persentase rata - rata $77,40 \%$ dari target yang diharapkan 
Khairurrizaq, Ismulhadi dan Dewi Ratih Ayu Daning, Penyuluhan Tentang Pembuatan Fermentasi Jerami Kangkung Menggunakan trichoderma,sp Sebagai Pakan Ternak Sapi Potong di Desa Babatan Kecamatan Balongpanggang

\section{DAFTAR PUSTAKA}

Ade S, Sudarsana, Ketut S. 2014. Analisis Sikap Dan Perilaku Konsumen Terhadap Pemilihan RumahTinggal Pada Kawasan Sunset Garden di Kota Denpasar, Bali. Jurnal Spektran Vol. 2. No. 1, Januari 2014

Ariyantis, YD. 2015. Kandungan Bahan Organik dan Protein Kasar Tongkol Jagung (Zea mays) yang Diinokulasi dengan Fungi Trichoderma sp. pada Lama Inkubasi yang Berbeda. Universitas Hasanuddin. Makasar. (Skripsi).

Dahlan, M. et al. 2013. Suplay Produksi Bahan Kering Jerami Kangkung Sebagai Bahan Pakan Ternak Ruminansia Di Kabupaten Lamongan. Jurnal Ternak, Vol.04, No.02

Eka, M M, Ferry F, Elida U, Makhfudli. 2014. Peningkatan Pengetahuan, Sikap, dan Ketrampilan Petugas Kesehatan Dalam Pelaksanaan Konseling Efektif TB Paru di Puskesmas Universitas Airlangga. Jurnal Sumber Daya Manusia Kesehatan Vol.1 No. 1, 2014. Penulis Korespondensi: Mar'ah Has, Alamat e-mail: eka.m.has@fkp.unair.ac.i

Gineung C U. 2010. Hubungan Pengetahuan, Sikap, Persepsi dan Keterampilan Mengendara Mahasaiswa Terhadap Prilaku Keselamatan Berkendara Di Universitas Gunadarma Bekasi 2009. Universitas Negeri Syarif Hidayatullah. Jakarta. Skripsi Untuk Memperoleh Gelar Sarjana Kesehatana Masyarakat

Lamid, M. et al. 2013. Potensi Complete Feed untuk Penggemukan Sapi Potong di Kabupaten Bangkalan. Universitas Airlangga, surabaya. Jurnal agroveteriner Vol. 2 - No. 1 / 2013-12 TOC : 7, and page : 53 - 59.

Ma'ruf. 2016. Rancangan Penyuluhan Sistem Tanam Jajar Legowo Pada Tanaman Padi sawah di Kecamatan Prajekan Kabupaten Bondowoso. STPP Malang. KIPA. Program Studi Penyuluhan Pertanian Sekolah Tinggi Penyuluhan Pertanian Malang

Megantoro, D. 2015. Pengaruh Keterampilan, Pengalaman, dan Kemampuan Sumber Daya Manusia (SDM) Terhadap Kinerja Usaha Kecil Menengah (UKM) Gerabah, (Studi Kasus Pada UKM Gerabah Di Desa Panjangrejo, Srihardono, Pundong, Bantul Yogyakarta). Skripsi. Yogyakarta, Agustus 2015.

Misbahul M H, Efendi F, Ulfiana E dan Makhfudy. 2014. Peningkatan Pengetahuan, Sikap, Dan Ketrampilan Petugas Kesehatan Dalam Pelaksanaan Konseling Efektif Tb Paru Di Puskesmas. Universitas Airlangga. Jurnal Sumber Daya Manusia Kesehatan Vol.1 No. 1, 2014

Nohong, B. et al. 2015. Kandungan Kalsium Dan Fospor Kombinasi Tumpi Jagung Dan Jerami Kacang Tanah Yang Terfermentasi. Univ. Muhammadiyah Makassar. Jurnal Galung Tropika, 4 (1) Januari 2015, Hlmn. 28-35 Issn Cetak 2302-4178

Rosa, F O. 2015. Analisis Kemampuan Siswa Kelas X pada Ranah Kognitif, Afektif dan Psikomotorik Friska Octavia Rosa Pendidikan Fisika, FKIP. Universitas Muhammadiyah Metro. Lampung. OMEGA Jurnal Fisika dan Pendidikan Fisika Vol 1, No 2 (2015) ISSN: 2443-2911E-mail: friskaoctaviarosa@ gmail.com 
Khairurrizaq, Ismulhadi dan Dewi Ratih Ayu Daning, Penyuluhan Tentang Pembuatan Fermentasi Jerami Kangkung Menggunakan trichoderma,sp Sebagai Pakan Ternak Sapi Potong di Desa Babatan Kecamatan Balongpanggang Kabupaten Gresik

Sitindaon, S H. 2013. Inventarisasi Potensi Bahan Pakan Ternak Ruminansia Di Provinsi Riau. Balai Pengkajian Teknologi Pertanian Riau. Jurnal Peternakan Vol 10 No 1 Februari 2013 (18 - 23) ISSN $1829-872918$

Sugiyono. 2016. Methode Penelitian Kombinasi (Mixed Methods). Alfabeta. Bandung

Sulaiman, N. 2009. Manajemen Pakan Pada Perusahaan Peternakan Sapi Potong. CV. Sumber Baja Perkasa Kabupaten Klaten. Universitas Sebelas Maret Surakarta

Supriyati, T et al. 2010. Fermentasi Jerami Padi Menggunakan Trichoderma viride. Balai Penelitian Ternak. Bogor. Seminar Nasional Teknologi Peternakan dan Veteriner 137. 